\title{
Penerapan Metode Struktural Analitik Sintetik (SAS) Terhadap Keterampilan Membaca Permulaan Di Kelas I SD Negeri 01 Padang Laweh Kabupaten Dharmasraya
}

\author{
Avinda Dwi Gusri Andini ${ }^{1)}$ \\ Faradilla Intan Sari ${ }^{2)}$ \\ Lika Apreasta ${ }^{3)}$ \\ 1) Fakultas Keguruan Dan Ilmu Pendidikan Universitas Dharmas Indonesia \\ Avindadwi3008@gmail.com
}

\begin{abstract}
ABSTRAK
Permasalahan penelitian ini adalah rendahnya kemampuan membaca siswa kelas I SD Negeri 01 Padang Laweh Kabupaten Dharmasraya. penelitian ini bertujuan untuk mengetahui pengaruh penerapan metode Struktural Analitik Sintetik (SAS) terhadap keterampilan membaca permulaan di kelas I SD Negeri 01 Padang Laweh, Kabupaten Dharmasraya. Jenis penelitian ini adalah eksperimen, dengan menggunakan jenis PreExperimental Design. Rancangan bentuk desain Pre- Experimental yang digunakan yaitu one group pretest-postest. Populasi dalam penelitian ini yaitu seluruh kelas I SD Negeri 01 Padang Laweh Kabupaten Dharmasraya. Teknik pengumpulan data dalam penelitian ini menggunakan tes hasil belajar (pre-test dan post-test) yaitu dengan tes soal yang bersifat tes soal uraian untuk mengukur keterampilan membaca permulaan siswa. Teknik analisis data menggunakan uji hipotesis melalui t dengan taraf nyata 0,05 . Hasil analisis data menunjukkan bahwa signifikan $0,000<0,05$ sehingga Ho ditolak dan Ha diterima. Artinya terdapat pengaruh penerapan metode metode Struktural Analitik Sintetik (SAS) terhadap keterampilan membaca permulaan di kelas I SD Negeri 01 Padang Laweh, Kabupaten Dharmasraya.
\end{abstract}

Kata kunci: metode Struktural Analitik Sintetik (SAS), keterampilan,membaca permulaan.

\section{ABSTRACT}

The problem of this research is the low reading ability of class I student at $S D$ Negeri 01 Padang Laweh, Dharmasraya. This study aims to determine the effect of the application of the Structural Analytical Syinthetic (SAS) method on beginner reading skills in grade I SD Negeri 01 Padang Laweh, Dharmasraya. This type of research is experimental, using the type of Pre- Experimental Design. The design of the preexerimental design used is one group pretest- posttest. The population in this study were all first graders of SD Negeri 01 Padang Laweh, Dharmasraya. Technique of data collection in this study used learning outcomes tests (pretest-posttest), namely by test question descriptions to measure students reading skills at the beginning. Analysis data used of this research was hypothesis test through $t$ test with a significance level of 0,05.The results of data analysis showed that it was significant $0,000<0,05$ so that Ho was rejected and Ha was accepted. This means that there is an effect of applying the 
Structural Analytical Synthetic (SAS) method to beginner reading skills in grade I SD Negeri 01 Padang Laweh, Dharmasraya.

Keywords: Structural Analytical Synthetic (SAS) method, skills, beginning reading.

\section{PENDAHULUAN}

Seiring dengan cepatnya perkembangan zaman, pemerintah telah menetapkan suatu tumpuan baru tentang tujuan pendidikan untuk diterapkan demi terciptanya sumber daya manusia yang mengerti ilmu pengetahuan dan teknologi (IPTEK). Pendidikan dalam suatu Negara sangat penting untuk kemajuan generasi bangsa, Undang-undang Nomor 20 tahun 2003 tentang Sistem Pendidikan Nasional menjelaskan bahwa: "Pendidikan adalah usaha sadar dan terencana untuk mewujudkan suasana belajar dan proses pembelajaran agar peserta didik secara aktif mengembangkan potensi dirinya untuk memiliki kekuatan spiritual, keagamaan, pengendalian diri, kepribadian, kecerdasan, akhlak mulia,serta keterampilan yang diperlukan dirinya, masyarakat, bangsa dan Negara".

Berdasarkan penjelasan Sisdiknas di atas, maka pendidikan merupakan hal yang sangat berharga dan mempunyai peran penting dalam pengembangan potensi peserta didik. Pendidikan dapat terlaksana melalui sebuah lembaga pendidikan yaitu lembaga pendidikan formal. Sekolah merupakan lembaga atau instansi yang membantu menumbuh kembangkan potensi dasar dari peserta didik. Sekolah merupakan tempat berlangsungnya kegiatan pembelajaran antara siswa dan guru. Kegiatan pembelajaran yang dihadapkan pada sejumlah mata pelajaran dengan tujuan agar siswa memiliki kemampuan sebagai modal dalam melanjutkan sekolah ke jenjang yang lebih tinggi,dan bermanfaat bagi dirinya dan masyarakat

Bahasa Indonesia merupakan pembelajaran tentang pengenalan bahasa yang digunakan dalam kehidupan sehari-hari, dimana setiap warga negara Indonesia wajib mengenal bahasa Indonesia yang baik dan benar. Senada dengan pendapat Jimi et al., (2014), mengatakan bahwa bahasa indonesia alat komunikasi utama oleh karena itu sejak dini anak-anak harus diarahkan agar mampu menggunakan bahasa indonesia yang baik dan benar. Bahasa Indonesia memegang peranan penting dalam upaya meningkatkan mutu pendidikan khususnya di Sekolah Dasar (SD) yakni mempercepat 
penguasaan ilmu pengetahuan dan Teknologi karena bahasa Indonesia merupakan sarana berfikir untuk menumbuhkan cara berfikir logis, sistematis dan kritis. Tujuan dari pembelajaran bahasa Indonesia di sekolah dasar yaitu agar siswa terampil dalam menggunakan bahasa dan mampu berkomunikasi secara efektif baik lisan maupun tertulis (Farhrohman, 1928).

Dalam pembelajaran bahasa Indonesia ada empat aspek keterampilan berbahasa yaitu keterampilan menyimak, berbicara, membaca dan menulis. Sejalan dengan pendapat Wardiyati, (2019), yang mengatakan bahwa pembelajaran bahasa Indonesia memiliki empat komponen keterampilan berbahasa yakni keterampilan menyimak, berbicara, membaca, dan menulis. Keempat aspek inilah yang akan menjadi dasar dari kebahasaan, dari empat aspek tersebut keterampilan membaca di sekolah dasar (SD) memegang peran penting dalam mengembangkan kemampuan berbahasa siswa. Keterampilan membaca bagi siswa sangat penting karena dengan memiliki keterampilan membaca dengan baik maka siswa akan mudah memahami mata pelajaran yang diajarkan di sekolah. Disamping itu membaca dapat membuka jendela pengetahuan,wawasan, informasi dan kemampuan siswa. Oleh karena itu, membaca dijadikan sebagai topik utama dalam pembelajaran bahasa Indonesia pada penelitian ini.

Kegiatan membaca pada kelas rendah dimulai pada tahap membaca. Membaca merupakan suatu kegiatan yang dimaksudkan untuk mendapatkan informasi dan pengetahuan dari teks yang dibaca. Hal ini sejalan dengan pendapat Wardiyati,( 2019), bahwa membaca adalah proses yang dilakukan oleh pembaca untuk memperoleh pemahaman serta informasi yang hendak disampaikan oleh penulis. Kegiatan membaca pada kelas rendah dimulai pada tahap membaca permulaan. Tahap membaca permulaan bertujuan untuk mengenalkan huruf- huruf kepada siswa. Apabila siswa sudah mengetahui huruf dan memadukannya menjadi kata maka selanjutnya siswa dituntun untuk melafalkan kata-kata tersebut. Senada dengan pendapat Wardiyati, (2019), yang mengatakan bahwa membaca permulaan merupakan tahap awal dalam belajar membaca yang difokuskan kepada mengenal simbol- simbol dan huruf-huruf. Menurut (Artana, I Putu Suarmei, 2014), tujuan membaca permulaan di kelas 1 SD yakni agar siswa dapat membaca huruf, kata dan kalimat sederhana dengan Lancar dan tepat. Kelancaran dan 
ketepatan anak membaca pada tahap belajar permulaan dipengaruhi oleh keaktifan dan kreativitas guru yang mengajar. Keterampilan membaca yang diperoleh pada membaca permulaan akan sangat berpengaruh terhadap keterampilan membaca lanjut. Tujuan membaca permulaan tidak terlepas dari tujuan pendidikan pada umumnya. Tujuan pengajaran membaca permulaan pada dasarnya adalah memberikan bekal pengetahuan dan kemampuan siswa untuk menguasai tehnik-tehnik membaca dan menangkap isi bacaan dengan baik dan benar.

Dalam pengajaran membaca permulaan sering ditemukan permasalahan siswa terhadap ketidak mampuan dalam membaca dan banyak dari mereka mengalami kendala dalam aspek pengelompokkan kata demi kata. Oleh karena itu, pendidik perlu memahami dan menggunakan metode yang tepat untuk mengajarkan anak dalam membaca permulaan. Berdasarkan observasi yang dilakukan peneliti pada siswa kelas I SD Negeri 01 Padang Laweh Kabupaten Dharmasraya ditemukan permasalahan dan kendala saat proses belajar mengajar yaitu masih banyak siswa yang kesulitan dalam membaca permulaan. Hal ini biasa terjadi pada siswa kelas I Sekolah Dasar (SD). Dari pengamatan diketahui bahwa dalam proses pembelajaran metode belajar yang digunakan kurang bervariasi dan menarik, siswa masih belum lancar membaca tetapi diharuskan mengikuti materi untuk mencapai kompetensi disetiap mata pelajaran, sehingga menyebabkan beberapa siswa kelas 1 yang belum dapat membaca menjadi tersendat-sendat. Hal tersebut menyebabkan peserta didik yang kurang bisa membaca merasa bosan dan malas-malasan dalam proses pembelajaran.

Data observasi dipertegas dengan wawancara peneliti dengan Wali kelas I yang mengatakan bahwa dalam proses belajar membaca, yaitu: 1) masih ada peserta didik yang belum mampu mengenal huruf atau masih lupa-lupa dengan huruf maka dalam latihan membaca harus dibantu pendidik untuk mengingatkannnya, 2) masih kurang dalam menggabungkan suku kata menjadi kata dari kata menjadi suatu kalimat, 3) dalam proses belajar membaca ada yang tidak peduli dan asik dengan teman bangku yang bermain atau membuat main-mainan pesawat-pesawatan. Penggunaan metode konvensional (ceramah) dalam proses pembelajaran menjadikan siswa cepat bosan dan jenuh dalam menerima pelajaran. Untuk mencegah permasalahan tersebut, Peneliti 
berpendapat bahwa dengan menerapkan metode pembelajaran yang tepat diharapkan dapat membantu keterampilan siswa dalam membaca permulaan di kelas. Metode yang akan diterapkan yaitu metode Struktural Analitik Sintetik (SAS), didalam metode SAS ini anak terlebih dahulu diperkenalkan pada satu unit bahasa terkecil yaitu kalimat. Kalimat tersebut kemudian diuraikan menjadi kata selanjutnya dari kata menjadi suku kata dan yang terakhir menjadi fonem (huruf). Huruf-huruf tersebut kemudian disintesiskan lagi menjadi suku kata, suku kata menjadi kata dan yang terakhir menjadi kalimat yang utuh kembali. Tujuan dari metode Struktural Analitik Sintetik adalah untuk meningkatkan keterampilan membaca permulaan. Metode Struktural Analitik Sintetik merupakan salah satu metode membaca dan menulis permulaan di kelas rendah. Metode ini merupakan metode yang wajib diterapkan di kelas rendah dengan harapan dapat meningkatkan kemampuan membaca dan menulis siswa. Pembelajaran MMP dengan metode ini mengawali pelajarannya dengan menampilkan dan mengenalkan sebuah kalimat utuh. Kalimat utuh pembelajaran membaca dan menulis permulaan ini diuraikan kedalam satuan-satuan bahasa yang lebih kecil yang disebut kata. Proses penganalisisan atau penguraian ini terus berlanjut hingga sampai satuan terkecil yakni huruf-huruf (Agustina, 2017).

Menurut Larasshinta, (2018), dalam penerapannya metode SAS menempuh langkah-langkah sebagai berikut: guru bercerita atau Tanya jawab dengan murid disertai gambar, membaca beberapa gambar, misalnya gambar ibu, ayah, dan anak, membaca beberapa kalimat dengan gambar, setelah hafal, dilanjutkan membaca tanpa bantuan gambar, menganalisis sebuah kalimat menjadi kata, suku kata, dan huruf kemudian mensinteskannya kembali menjadi kalimat.

Adapun kelebihan metode Struktural Analitik Sintetik (SAS) yaitu: 1) Metode ini dapat sebagai landasan berfikir analisis 2) Dengan langkah yang diatur sedemikian rupa membuat anak mudah mengikuti prosedur dan akan cepat membaca pada kesempatan berikutnya 3) Berdasarkan landasan linguistik metode ini akan menolong anak menguasai bacaan dengan lancar (Global et al., 2017). Hasil penelitian Inpres et al., (2018), menunjukkan bahwa: kemampuan membaca permulaan murid kelas 1 SD Inpres Bontomanai Kota Makassar melalui penerapan metode SAS dapat meningkatkan 
kemampuan membaca siswa berdasarkan dengan data yang diperoleh yakni kemampuan murid dalam membaca permulaan dari segi kualitatif dan kuantitatif (nilai rata-rata hasil tes kemampuan membaca permulaan), yaitu: siklus I dalam kategori cukup mampu dengan nilai 53,66, kemudian meningkat menjadi kategori mampu membaca permulaan pada siklus II dengan nilai 65,5. Berdasarkan pemaparan latar belakang masalah di atas, maka peneliti tertarik melakukan penelitian dengan judul "Penerapan Metode Struktural Analitik Sintetik (SAS) Terhadap Keterampilan Membaca Permulaan di Kelas I SD Negeri 01 Padang Laweh Kabupaten Dharmasraya”.

\section{METODE PENELITIAN}

Penelitian ini dilakukan dengan menggunakan pendekatan kuantitatif. Metode pendekatan kuantitatif dapat diartikan sebagai metode penelitian yang berlandaskan pada filsafat positivisme, digunakan untuk meneliti pada populasi atau sampel tertentu, pengumpulan data menggunakan instrumen penelitian, analisis data bersifat kuantitatif/statistik, dengan tujuan untuk menguji hipotesis yang telah ditetapkan. Desain penelitian yang digunakan yaitu pre-eksperimental design. Dikatakan preeksperimental design, karena desain ini belum merupakan eksperimen sungguh-sungguh. Mengapa?, karena masih terdapat variabel luar yang ikut berpengaruh terhadap terbentuknya variabel dependen. Jadi hasil eksperimen yang merupakan variabel dependen ini bukan semata-mata dipengaruhi oleh variabel independen. Hal ini dapat terjadi karena tidak adanya variabel kontrol, dan sampel tidak dipilih secara random (Sugiyono, 2016). Metode yang digunakan dalam penelitian ini adalah metode eksperimen dengan bentuk one group pretest-posttest. Desain ini menggunakan satu kelompok yaitu kelas eksperimen.

Penelitian dilaksanakan pada kelas I di SD Negeri 01 Padang Laweh Kabupaten Dharmasraya, Provinsi Sumatra Barat. Waktu penelitian ini dilaksanakan pada semester ganjil tahun ajaran 2021/2022.

Populasi dalam penelitian ini adalah seluruh siswa kelas I SD Negeri 01 Padang Laweh yang berjumlah 18 siswa. Teknik sampling yang akan digunakan dalam penelitian ini adalah Non Probability Sampling. Teknik pengambilan sampel yang tidak memberikan peluang yang sama bagi setiap unsur (anggota) populasi untuk dipilih 
menjadi anggota sampel. Sedangkan jenis sampel yang digunakan dalam penelitian ini adalah Sampel jenuh. Teknik ini penelitian ini adalah Sampel jenuh. Teknik ini merupakan teknik penentuan sampel bila semua anggota atau populasi digunakan sebagai sampel. Teknik ini sering kali dipergunakan dalam pengambilan sampel penelitian eksperimen dibidang pendidikan, dimana jumlah populasi penelitian relatif sedikit, yaitu kurang dari 100 orang dan kurang dari 3 kelas (Jakni, 2016). Dalam penelitian ini, mengambil sampel sebanyak 1 kelas yang dijadikan kelas eksperimen yaitu siswa kelas I SD Negeri 01 Padang Laweh Kabupaten Dharmasraya.

Teknik pengumpulan data dalam penelitian ini yaitu teknik tes. Tes yang digunakan dalam penelitian ini merupakan tes tertulis yaitu : Tes awal (pre-test) dan Tes akhir (post-test). Teknik analisis yang dilakukan adalah menggunakan teknik analisis data statistik. Analisis data ini digunakan untuk menganalisis data kuantitatif yang berupa hasil belajar peserta didik dengan diolah melalui aplikasi statistik yaitu SPSS 25 for windows. Langkah-langkah yang ditempuh dalam penggunaan statistik pengolahan data yaitu (a) Uji normalitas dan (b) Uji Hipotetsis yang dijelaskan sebagai berikut:

\section{Uji Normalitas Data}

Uji normalitas data adalah pengujian yang dilakukan untuk mengetahui normal tidaknya persebaran data yang akan dianalisis. Uji normalitas yang digunakan yaitu Shapiro-Wilk dengan menggunakan SPSS 25 for windows. Cara mengetahui Signifikansi (sig) adalah dengan memperhatikan angka pada kolom signifikansi (sig), kriteria uji normalitas sebagai berikut:

Tetapkan taraf signifikansi (sig) yang diperoleh $\alpha=0,05$

Bandingkan dengan taraf signifikansi (sig) yang diperoleh $\alpha$

Jika signifikansi (sig) yang diperoleh $>\alpha$ maka data distribusi normal

Jika signifikansi (sig) yang diperoleh $<\alpha$ maka data distribusi tidak normal.

Uji Hipotesis

Data yang terkumpul dari penelitian yang telah dilakukan dianalisis untuk mengetahui hasil dari penelitian tersebut. Analisis data akan membuktikan apakah hipotesis yang diajukan diterima atau ditolak. Pada penelitian ini peneliti menggunakan uji hipotesis test dengan bantuan program statistik (SPSS 25). 


\section{HASIL DAN PEMBAHASAN}

Penelitian yang dilakukan menghasilkan data skor pre-test dan post test yang diberikan kepada kelas eksperimen dengan jumlah 10 butir soal uraian dimana pada setiap soal mengandung indikator membaca permulaan pada mata pelajaran Bahasa Indonesia. Dalam penelitian tersebut bertujuan untuk melihat pengaruh penerapan metode Struktural Analitik Sintetik (SAS) terhadap keterampilan membaca permulaan di kelas I sebelum perlakuan dan sesudah perlakuan.

Tabel 7 data hasil pre-test dan post-test siswa

\begin{tabular}{|c|c|c|}
\hline Deskripsi data & Pre-test & Post-test \\
\hline $\mathrm{N}$ & 18 & 18 \\
\hline$\sum X$ & 972,5 & 1380 \\
\hline $\bar{x}$ & 54,02 & 76,66 \\
\hline Xmaks & 92,5 & 95 \\
\hline Xmin & & 47,5 \\
\hline$\%$ Ketuntasan & $25 \%$ & $66 \%$ \\
\hline
\end{tabular}

Berdasarkan analisis data pre-test dan post-test siswa diperoleh nilai rata-rata pre-test $=54,02$ dan nilai post-test $=76,66$. Berdasarkan nilai rata-rata tersebut terlihat bahwa nilai rata-rata post-test lebih baik dari pada nilai rata-rata pre-test. 
Tabel 8 Hasil Uji Normalitas pre-test dan post-test

\begin{tabular}{|c|c|c|c|c|c|c|}
\hline \multicolumn{7}{|c|}{ Tests of Normality } \\
\hline & \multicolumn{3}{|c|}{ Kolmogorov-Smirnov ${ }^{a}$} & \multicolumn{3}{|c|}{ Shapiro-Wilk } \\
\hline & $\begin{array}{l}\text { Stat } \\
\text { istic }\end{array}$ & $d f$ & Sig. & $\begin{array}{r}S t \\
\text { atistic }\end{array}$ & $d f$ & sig. \\
\hline $\begin{array}{l}\text { Hasil } \\
\text { belajar } \\
\text { siswa } \\
\text { pretest }\end{array}$ & $\begin{array}{r}11 \\
7\end{array}$ & $\begin{array}{l}1 \\
8\end{array}$ & $\begin{array}{r}20 \\
0^{*}\end{array}$ & $\begin{array}{l}, 9 \\
65\end{array}$ & $\begin{array}{l}1 \\
8\end{array}$ & $\begin{array}{r}, 70 \\
1\end{array}$ \\
\hline $\begin{array}{l}\text { Hasil } \\
\text { belajar } \\
\text { siswa } \\
\text { posttest }\end{array}$ & $\begin{array}{r}, 11 \\
0\end{array}$ & $\begin{array}{l}1 \\
8\end{array}$ & $\begin{array}{r}20 \\
0^{*}\end{array}$ & $\begin{array}{l}, 9 \\
51\end{array}$ & $\begin{array}{l}1 \\
8\end{array}$ & $\begin{array}{r}, 43 \\
3\end{array}$ \\
\hline
\end{tabular}

Berdasarkan uji normalitas pada tabel diatas dari test Shapiro-Wilk diperoleh data pretest kelas eksperimen adalah 0,701 dan data post-test adalah 0,433 dengan $a=0,05$ maka uji normalitas dari data hasil pre-test kelas eksperimen adalah signifikan 0,701 > 0,05 dan hasil post-test adalah signifikan 0,433 >0,05. Sehingga dapat disimpulkan bahwa data hasil pre-test dan post-test kelas eksperimen berdistribusi normal.

Tabel 9 Hasil uji Paired Sample t test

\begin{tabular}{|c|c|c|c|c|c|c|c|}
\hline \multicolumn{8}{|c|}{ Paired Samples Test } \\
\hline \multicolumn{5}{|c|}{ Paired Differences } & & & \\
\hline \multirow[b]{2}{*}{$\begin{array}{l}\text { Me } \\
\text { an }\end{array}$} & \multirow{2}{*}{$\begin{array}{c}\text { td. } \\
\text { Deviati } \\
\text { on }\end{array}$} & \multirow{2}{*}{$\begin{array}{c}\text { td. } \\
\text { Error } \\
\text { Mean }\end{array}$} & \multicolumn{2}{|c|}{$\begin{array}{r}95 \% \\
\text { Confidence } \\
\text { Interval of } \\
\text { the Difference }\end{array}$} & & & Si \\
\hline & & & ower & $\begin{array}{l}U \\
\text { pper }\end{array}$ & $t$ & $d f$ & $\begin{array}{l}\text { g. }(2- \\
\text { tailed })\end{array}$ \\
\hline
\end{tabular}

214 | Jurnal CONSILIUM (Education and Counseling Journal) 


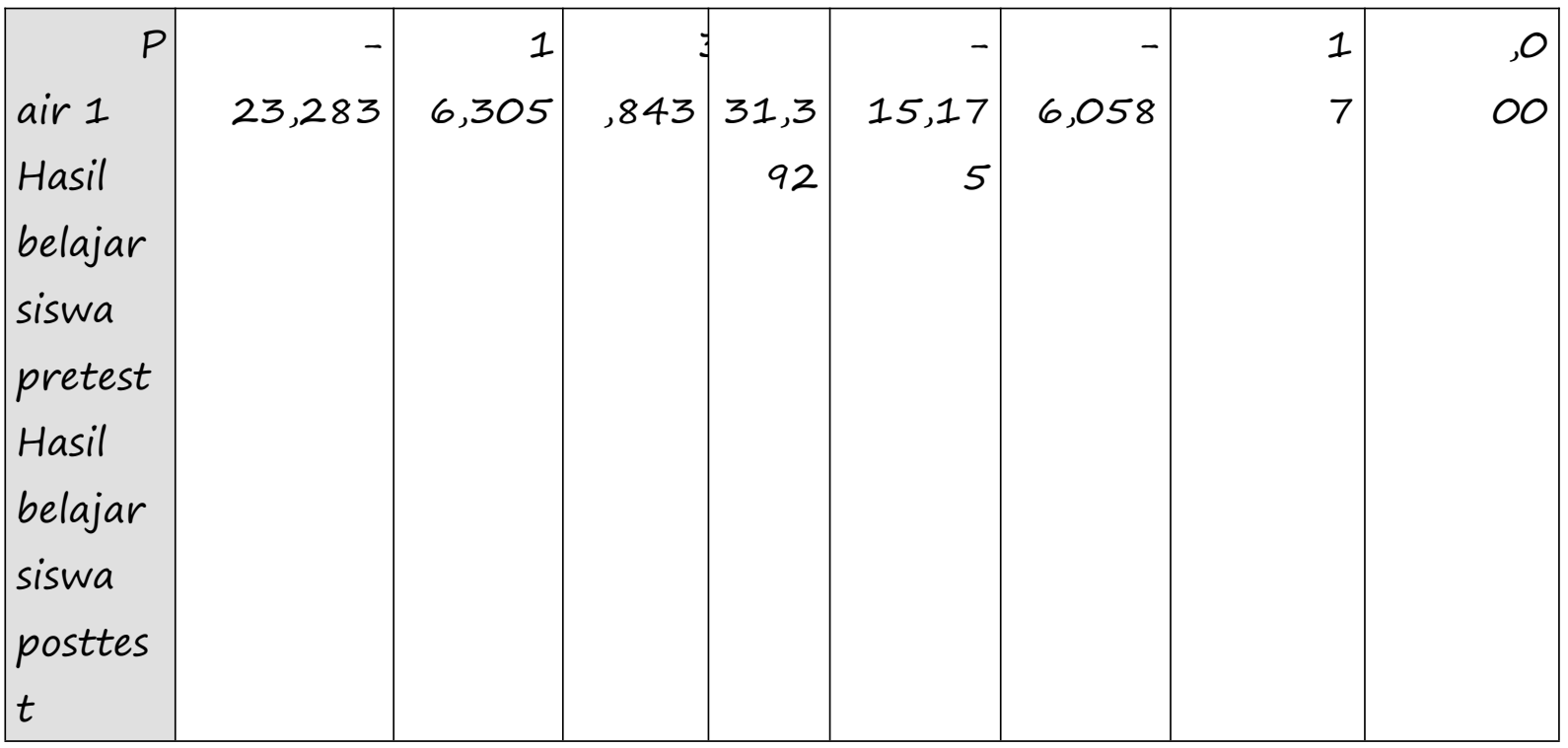

Berdasarkan tabel di atas diperoleh signifikan 0,000 pada taraf signifikan 0,05. Hasil perhitungan diperoleh Sig $<a(0,000<0,05)$ yang berarti uji t tidak berada pada daerah penerimaan Ho sehingga dapat disimpulkan bahwa Ho ditolak dan Ha diterima. Dengan demikian hipotesis yang diajukan dalam penelitian ini terbukti "terdapat pengaruh yang signifikan penerapan metode Struktural Analitik Sintetik (SAS) terhadap keterampilan membaca permulaan di kelas I SD Negeri 01 Padang Laweh Kabupaten Dharmasraya".

Keterampilan membaca permulaan merupakan keterampilan yang lebih diorientasikan pada keterampilan membaca tingkat dasar, yakni kemampuan melek huruf. Dimana siswa mampu mengenal huruf, membedakan huruf, mengidentifikasi dan merangkaii huruf menjadi suku kata hingga kata atau kalimat. Pada penelitian ini pengaruh metode Struktural Analitik Sintetik (SAS) terhadap keterampilan membaca permulaan ditentukan dari perbandingan hasil belajar siswa pada saat pre-test dan posttest.

Berdasarkan penelitian dan pengujian hipotesis yang telah dilakukan memperlihatkan hasil dari signifikansi yang menunjukkan bahwa sig 0,000<0,05 yang artinya terdapat pengaruh terhadap metode yang di terapkan di kelas eksperimen. Kelas eksperimen dalam penelitian ini menggunakan Struktural Analitik Sintetik (SAS) terhadap keterampilan membaca permulaan di kelas I SD Negeri 01 Padang Laweh 
Kabupaten Dharmasraya. Hasil belajar peserta didik pada kelas eksperimen sebelum diberikan perlakuan (pre-test) diperolah rata-rata nilai 54,02 sedangkan rata-rata nilai yang diperoleh setelah diberi perlakuan (post-test) yaitu 76,66. Kemudian sebelum melakukan pengujian hipotesis langkah awal yang dilakukan adalah dengan melakukan pengujian persyaratan analisis yaitu menggunakan uji normalitas. Setelah dilakukan syarat pengujian tersebut, didapatkan bahwa data penelitian berdistribusi normal. Langkah selanjutnya melakukan pengujian dengan menggunakan hipotesis parametrik yaitu uji t paired sample test.

Berdasarkan pengujian hipotesis diperoleh signifikan 0,000 pada taraf signifikan 0,05 . Hasil perhitungan diperoleh $\operatorname{Sig}<\mathrm{a}(0,000<0,05)$ yang berarti uji t tidak berada pada daerah penerimaan Ho sehingga dapat disimpulkan bahwa Ho ditolak dan Ha diterima. Dengan demikian hipotesis yang diajukan dalam penelitian ini terbukti "terdapat pengaruh yang signifikan penerapan metode Struktural Analitik Sintetik (SAS) terhadap keterampilan membaca permulaan di kelas I SD Negeri 01 Padang Laweh Kabupaten Dharmasraya".Menurut Emgusnadi, dalam (Wardiyati, 2019) menyatakan bahwa, metode Struktural analitik sintetik atau yang biasa disingkat dengan SAS merupakan salah satu metode yang dapat digunakan dalam pembelajaran membaca dan menulis permulaan. Metode SAS merupakan metode pembelajaran yang digunakan untuk mengupas dan merangkai kata dengan cara melihat struktur penuh, lalu menganalisa dan mengetahui satu per satu unsur bacaan dari suatu kata atau kalimat. Saat melakuan penelitian pada kelas eksprimen, dalam proses pembelajaran peneliti menerapkan langkah-langkah yang ada pada metode Struktural analitik sintetik (SAS). Menurut Emgusnadi, ada 5 langkah-langkah metode pembelajaran SAS. Adapun langkah-langkah yang harus dilakukan oleh guru yaitu 1) Guru membimbing siswa mengamati sebuah gambar yang ada dipapan tulis dan memberikan beberapa pertanyaan kepada siswa, 2) guru memberikan kesempatan kepada siswa untuk membaca berdasarkan gambar dan kalimat sederhana dengan membaca kalimat secara struktural caranya adalah menghilangkan gambar sehingga tinggal lah kalimat yang dibaca oleh siswa, 3) guru membimbing siswa melakukan analisis terhadap struktur dengan cara memisah-misahkannya menjadi kata, kata menjadi suku kata, dan suku kata menjadi huruf, 4) guru membimbing siswa melakukan proses sintesis dengan cara 
menggabungkan kembali setiap unsur tersebut menjadi struktur lengkap kalimat seperti semula, 5) guru membimbing siswa dalam membuat kesimpulan. Ada beberapa keunggulan dalam menerapkan metode SAS, adapun keunggulan dalam menerapkan metode SAS yaitu: metode ini dapat sebagai landasan berpikir analisis siswa di sekolah dasar, dengan langkah-langkah yang diatur dengan baik membuat siswa lebih mudah mengikuti prosedur membaca, dapat membantu siswa menjadi lebih mudah menguasai bacaan dengan lancar. Kelima langkah-langkah tersebut menyebabkan pembelajaran yang dialami peserta didik menjadi bermakna. Peserta didik dapat mudah mengingat tahapan-tahapan dalam belajar membaca, mulai dari membaca kalimat sederhana, kata, suku kata dan huruf. Penelitian ini dapat disimpulkan terdapat pengaruh penerapan motode Struktural Analitik Sintetik (SAS) terhadap keterampilan membaca permulaan di kelas I SD Negeri 01 Padang Laweh Kabupaten Dharmasraya.

\section{KESIMPULAN}

Setelah melakukan penelitian terhadap pengaruh penerapan metode Struktural Analitik Sintetik (SAS) di kelas I SDN 01 Padang Laweh Kabupaten Dharmasraya. Kemudian melakukan pengolahan data, dapat ditarik kesimpulan bahwa penerapan metode Struktural Analitik Sintetik (SAS) dalam pembelajaran di kelas berpengaruh terhadap keterampilan membaca permulaan di kelas I SDN 01 Padang Laweh Kabupaten Dharmasraya. Hasil tersebut dapat ditunjukkan dengan uji hipotesis yang menunjukkan bahwa nilai signifikan 0,000 pada taraf signifikan 0,05. Selain itu juga dapat dilihat dari rata-rata nilai pre-test pada kelas eksperimen yaitu 54,02 sedangkan rata-rata nilai post-test pada kelas eksperimen yaitu 76,66.

\section{SARAN}

Penggunaan metode Struktural Analitik Sintetik (SAS) ternyata mampu mempengaruhi hasil belajar keterampilan membaca permulaan bagi siswa kelas I, maka disarankan kepada:

Guru dalam proses pembelajaran khususnya pada mata pelajaran bahasa Indonesia hendaknya dapat menggunakan metode pembelajaran yang dapat menumbuhkan sikap berfikir inkuiri serta menumbuhkan semangat belajar siswa sehingga dapat meningkatkan keterampilan membaca siswa. Salah satu metode yang dapat digunakan 
yaitu metode Struktural Analitik Sintetik (SAS), karena metode ini terbukti berpengaruh terhadap hasil belajar keterampilan membaca permulaan pada siswa kelas I dalam penelitian ini.

Peneliti lebih lanjut agar penelitian ini dapat memberikan manfaat bagi banyak orang, maka perlu diadakan penelitian tindak lanjutan dari penelitian ini. Sehingga siswa di kelas rendah di sekolah dasar lainnya juga dapat menambah ilmu pengetahuan dan wawasan khususnya dalam meningkatkan keterampilan membaca permulaan.

\section{DAFTAR RUJUKAN}

Agustina, I. (2017). Penerapan Metode Sas Untuk Huruf Tegak Bersambung Kelas I Sd. Ii(Iii), 75-83.

Artana, I Putu Suarmei, D. (2014). Pengaruh Metode Sas Berbantuan Media Kartu Huruf Terhadap Keterampilan Membaca Dan Menulis. Jurnal Mimbar Pgsd Universitas Pendidikan Ganesha, 2.

Farhrohman, O. (1928). Implementasi Pembelajaran Bahasa Indonesia Di Sd / Mi. 2334.

Global, M., Meningkatkan, U., Dan, M., Peserta, B., Pada, D., Pelajaran, M., \& Indonesia, B. (2017). Penerapan Metode Sasmg (Struktural Analitik Sintetik Dan Matode Global) Untuk Meningkatkan Motivasi Dan Hasil Belajar Peserta Didik Pada Mata Pelajaran Bahasa Indonesia Kelas I Di Sdn 3 Kopang Kec. Kopang Tahun Pelajaran 2015/2016. 3(2), 51-56.

Inpres, S. D., Kecamatan, B., \& Kota, T. (2018). Penerapan Metode Struktural Analitik Sintetik Dalam Meningkatkan Kemampuan Membaca Permulaan Murid Kelas I Sd Inpres Bontomanai Kecamatan Tamalate Kota Makassar. 1(1).

Jakni. (2016). Metodologi Penelitian Eksperimen Bidang Pendidikan. Alfabeta.

Jimi, K., Dewi, K., Suwatra, I. I. W., \& Arini, N. W. (2014). Penggunaan Metode Struktur Analitik Sintetik (Sas) Untuk Meningkatkan Kemampuan Membaca Menulis Permulaan Pada Siswa Kelas I Sd Negeri 7 Bungkulan Jurusan Pendidikan Guru Sekolah Dasar, Fip Universitas Pendidikan Ganesha E-Journal Mimbar Pgsd Universitas. Mimbar Pgsd Universitas Pendidikan Ganesha, 2(1).

Larasshinta, D. (2018). Penerapan Metode Sas (Struktural Analitik Sintetik) Pada Pembelajaran Membaca Permulaan Siswa Kelas 1 Mi Ma'arif Nu Sokawera Padamara Purbalingga Tahun Pelajaran 2017/2018.

Sugiyono. (2016). Metode Penelitian Kuantitatif, Kualitatif, Dan R\&D. Alfabeta.

Wardiyati, H. (2019). Penerapan Metode Sas (Struktural Analitik Sintetik) Untuk Meningkatkan Keterampilan Membaca Siswa Kelas Rendah. 3(September), 10831091. 